\title{
SHAD SPECIES IN GREEK WATERS - AN HISTORICAL OVERVIEW AND PRESENT STATUS.
}

\author{
D.C. BOBORI (1), E.T. KOUTRAKIS (2), P.S. ECONOMIDIS (1)
}

(1) Aristotle University, School of Biology, Laboratory of Ichthyology, Box 134, GR-540 06 THESSALONIKI, Greece, Tel. +30.31.99.82.65, Fax +30.31.99.82.79.

E-mail : PSEcon@bio.auth.gr

(2) National Agricultural Research Foundation, Fisheries Research Institute of Kavala, GR-64007 NEA PERAMOS, Kavala, Greece.

\section{SUMMARY}

An historical overview of the shad species in Greek waters and the present status of these species are given. The species Alosa fallax (Lacépède, 1803), Alosa macedonica (Vinciguerra, 1921) and Alosa vistonica (Economidis and Sinis, 1986), are the three kinds of shad thriving in Greek waters. The Alosa fallax regularly occurs across coastal zones, mainly near estuaries, and enters the rivers such as Evros, Nestos, Strymon (Thrace and Macedonia), Pinios (Thessaly), Acheloos and Thyamis (western Greece), during the spawning period. Its presence is also confirmed in lake Vistonis, which is connected with the Thracian Sea and there is also strong evidence that it enters some other rivers such as Loudias (Macedonia), Louros and Arachthos (western Greece). Alosa macedonica is a landlocked species endemic to lake Volvi, whereas Alosa vistonica is also endemic and landlocked in the lacustrine part of the lagoon Vistonis.

\section{LES ALOSES DES EAUX GRECQUES - APPROCHE HISTORIQUE ET SITUATION ACTUELLE.}

\section{RÉSUMÉ}

Les auteurs présentent une vue historique de la situatin des espèces d'aloses vivant dans les eaux grecques, ainsi que leur statut actuel. Alosa fallax (Lacépède, 1803), Alosa macedonica (Vinciguerra, 1921) et Alosa vistonica (Economidis et Sinis, 1986), sont les trois espèces qui fréquentent les eaux du pays. La première espèce est présente le long de la zone côtière, principalement à proximité des estuaires. Elle entre dans les rivières Evros, Nestos, Strymon (Thrace et Macédoine), Pinios (Thessalie), Acheloos et Thyamis (Grèce de l'ouest) durant la période de reproduction. Sa présence est également confirmée pour la partie lagunaire du lac Vistonis, qui est ouvert sur la mer de Thrace. II existe également des preuves indéniables de sa présence sur les rivières Loudias (Macédoine), Louros et Arachthos (Grèce de l'Ouest). Alosa macedonica et Alosa vistonica sont deux espèces exclusivement dulçaquicoles, respectivement endémiques des lacs Volvi et Vistonis. 


\section{INTRODUCTION}

The species belonging to the genus Alosa (shads) are marine pelagic, mostly anadromous or semianadromous, but some purely freshwater species (subspecies or races) exist ; except where landlocked they also are schooling, migratory and distributed in Mediterranean, Black and Caspian Seas and eastern and western North Atlantic (WHITEHEAD, 1985).

In Greek waters the following three shad species are found (Figure 1) : Alosa fallax (Lacépède, 1803), Alosa macedonica (Vinciguerra, 1921) and Alosa vistonica (Economidis and Sinis, 1986). Alosa fallax (En : Twaite shad, Gr: Sardelomana) regularly occurs across coastal zones, mainly near estuaries, and enters the rivers during the spawning period. Alosa macedonica (En : Macedonian shad, Gr : Liparia) and Alosa vistonica (En : Thracian shad, Gr : Thritsa) are landlocked species endemic to lake Volvi and to lake Vistonis respectively. In the following presentation a new approach and an up-to-date contribution on the recent status of these species in Greek waters are given. The taxonomy of the species discussed follows KOTTELAT (1997).

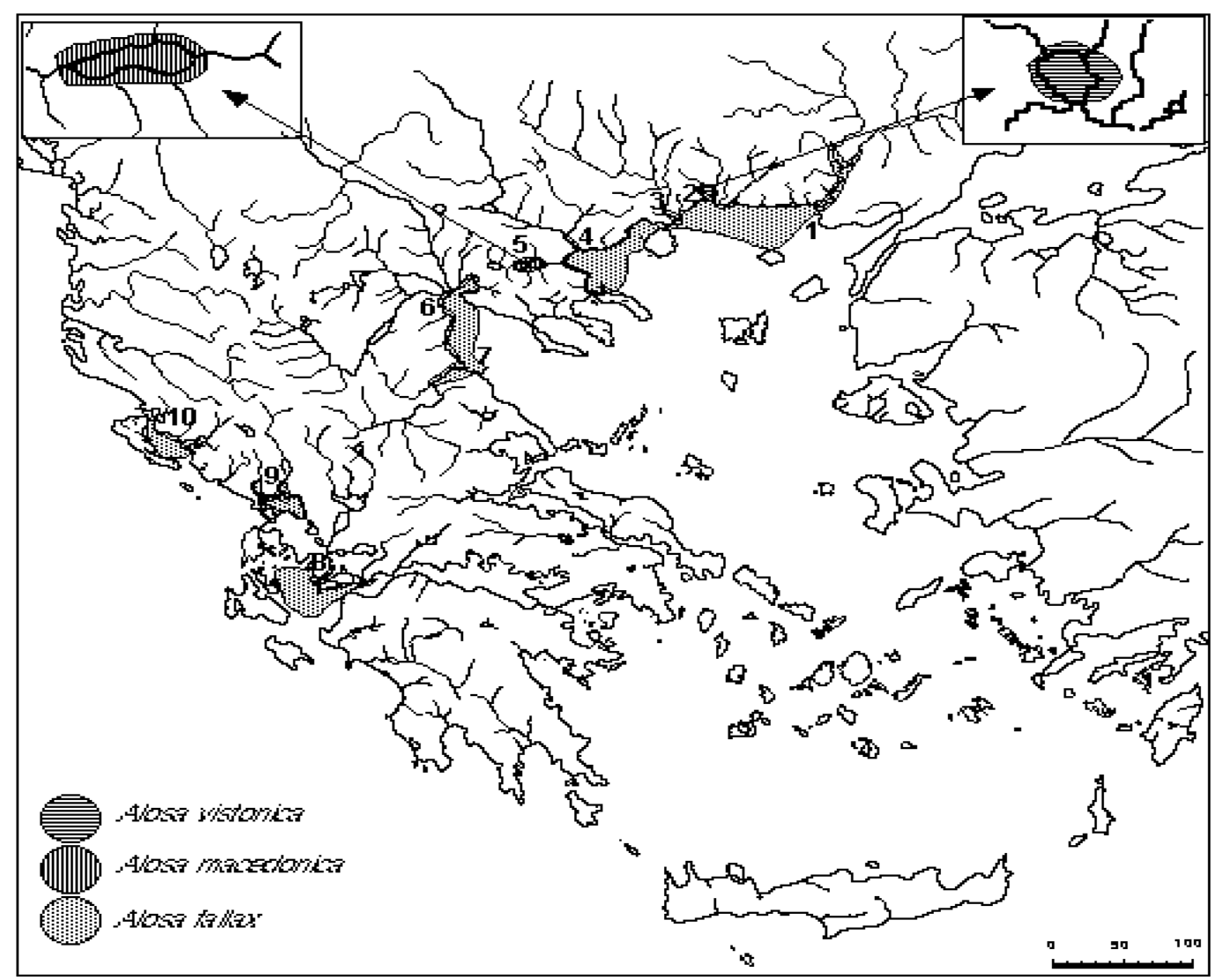

Figure 1

Distribution of the three shad species in Greece. Rivers and lakes. 1. Evros, 2. Vistonis, 3. Nestos, 4. Strymon, 5. Volvi, 6. Axios, Loudias and Aliakmon, 7. Pineios (Thessaly), 8. Acheloos, 9. Arachthos and Louros, 10. Thyamis.

\section{Figure 1}

Distribution des trois espèces des aloses en Grèce. Rivières et lacs : 1. Evros, 2. Vistonis, 3. Nestos, 4. Strymon, 5. Volvi, 6. Axios, Loudias et Aliakmon, 7. Pineios (Thessalie), 8. Acheloos, 9. Arachthos et Louros, 10. Thyamis. 


\section{METHODS}

All information presented here comes from : (a) recent sampling conducted by local fishermen in several target areas ; (b) previous historical fish collections, including typematerial, deposited mainly in the laboratory of Ichthyology of the Aristotle University ; (c) simple questionnaires focusing on the local frequency, the morphological and other characteristics, the migration habits, the fishing practices, etc., regarding the species, which are distributed in the areas concerned and (d) any previous unpublished data and proper literature. Data on annual fish production were provided by the Greek National Fisheries Authority and some unpublished biological observations are also included.

\section{RESULTS}

Alosa macedonica (Vinciguerra, 1921) (Macedonian shad or Liparia) (Figure 2) is an exclusively freshwater species considered to have been isolated in lake Volvi in a glacial period prior to the most recent one (ECONOMIDIS and SINIS, 1986). According to SINIS (1981), the ancestors of this species might have inhabited the marine regions of the northern Aegean Sea during the lower quaternary and moved to the lake Volvi system when it was flowing into the sea. Actually, there is a rather narrow waterway connecting the lake with the sea through the Rentina valley that was established during the last glacial periods (PSILOVIKOS, 1977). The small rivulet flowing through prevents any serious migration to the sea and visa-versa.

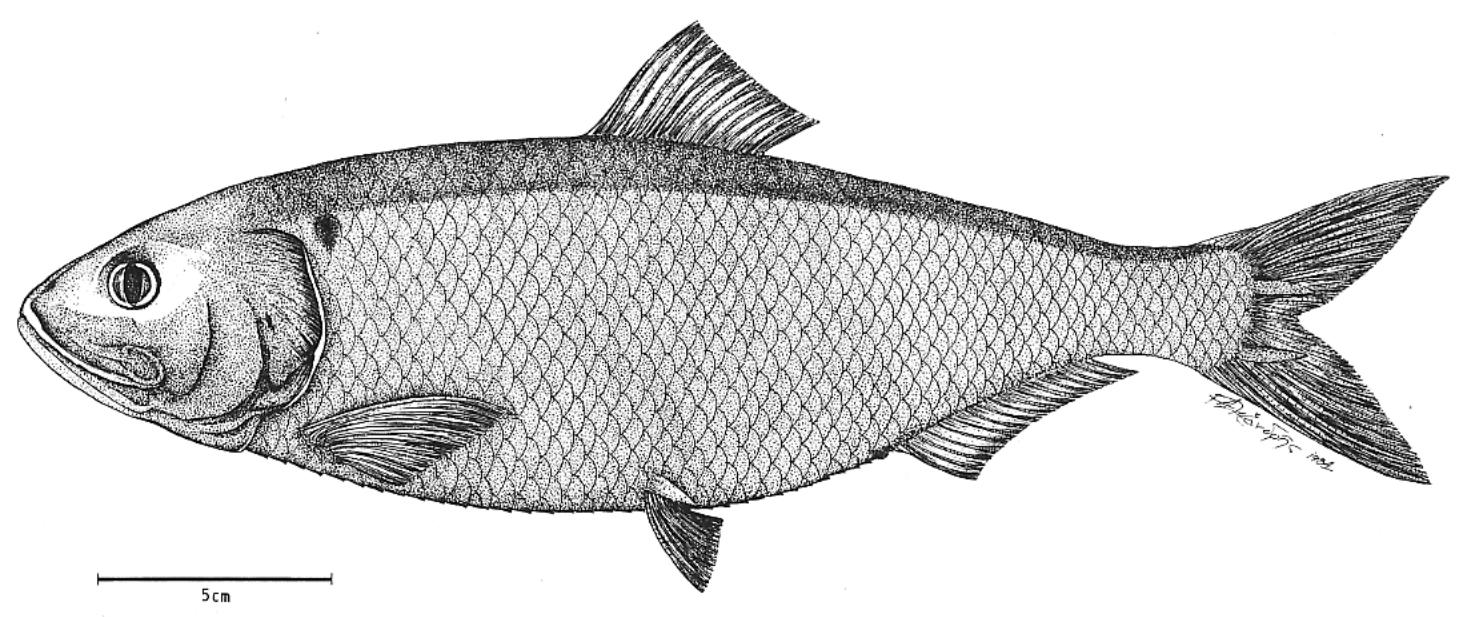

\section{Figure 2}

Alosa macedonica (Vinciguerra, 1921) (from ECONOMIDIS and SINIS, 1986).

\section{Figure 2}

Alosa macedonica (Vinciguerra, 1921) (d'après ECONOMIDIS et SINIS, 1986).

The Macedonian shad is characterized by having teeth in the palatines and vomer, 48-50 vertebrae, and 106-128 gillrakers. Based merely on these characteristics ECONOMIDIS and SINIS (1986) revised any previous taxonomy and ranked the fish to a valid species level, related to Pontocaspian stock rather than those of the Atlantic, as believed before (BERG, 1933, 1948 ; SVETOVIDOV, 1952, etc.). Apparently, the isolation of the species in lake Volvi could be attributed to the increase of salinity in the Thracian Sea (North Aegean Sea) compared to that of the Black Sea. 
The holobiotic adaptation of the fish in freshwater life had some remarkable changes in its biology. The most important change is in the breeding period which shifted from springtime to July-August (SINIS, 1981 ; SINIS and KATTOULAS, 1986). Regarding age and growth SINIS (1981) and SINIS and KATTOULAS (1986) recognized four age classes and the age class III was dominant within the years 1974-1977. Moreover, individuals of $181-230 \mathrm{~mm}$ total length formed the main bulk of the samples (60\%) and the females predominated in the population (62-97\%) with a sex ratio of 1:2.64.

The Macedonian shad was one of the most fished species in Volvi, comprising periodically up to $68 \%$ of the total annual catch of the lake (Figure 3). However, during the last ten years it is no longer captured systematically, because of its low commercial value, except in small quantities in early summer, which are salted by the fishermen. The low fishing impact on the shad along with the intense fishing of its predators led to an increase of its population. This resulted in serious food chain disturbances and, by extension, affected the size of the other sympatrically living fish populations. Moreover, today the species is undesirable by the fishermen because of the difficulties they have to clear the nets of by-catch. According to ZARFDJIAN et al. (1995) the species could be considered responsible for a strong predation upon the large zooplankton and consequently for its low grazing action on the phytoplankton of the lake. This fact sometimes causes unexpected water algae blooms. Furthermore, this feeding behavior is antagonistic to Cyprinus carpio juveniles that are also feed on large zooplankton. Additionally, stomach contents have shown that the Macedonian shad has another, rather opportunistic feeding behavior consuming, almost regularly and mainly near banks, small size fish or juveniles of Knipowitschia caucasica, small Rutilus rutilus, Alburnus alburnus, Rhodeus amarus, etc. (ECONOMIDIS and SINIS, 1991a). Moreover, according to SINIS and KALFAPAPAIOANNOU (1988), almost the whole population (100\% of the samples caught) is infected by Ergasilus sieboldi. This may be a result of the uncontrolled increase of the shad population, as the predators of the species in the lake are heavily fished.

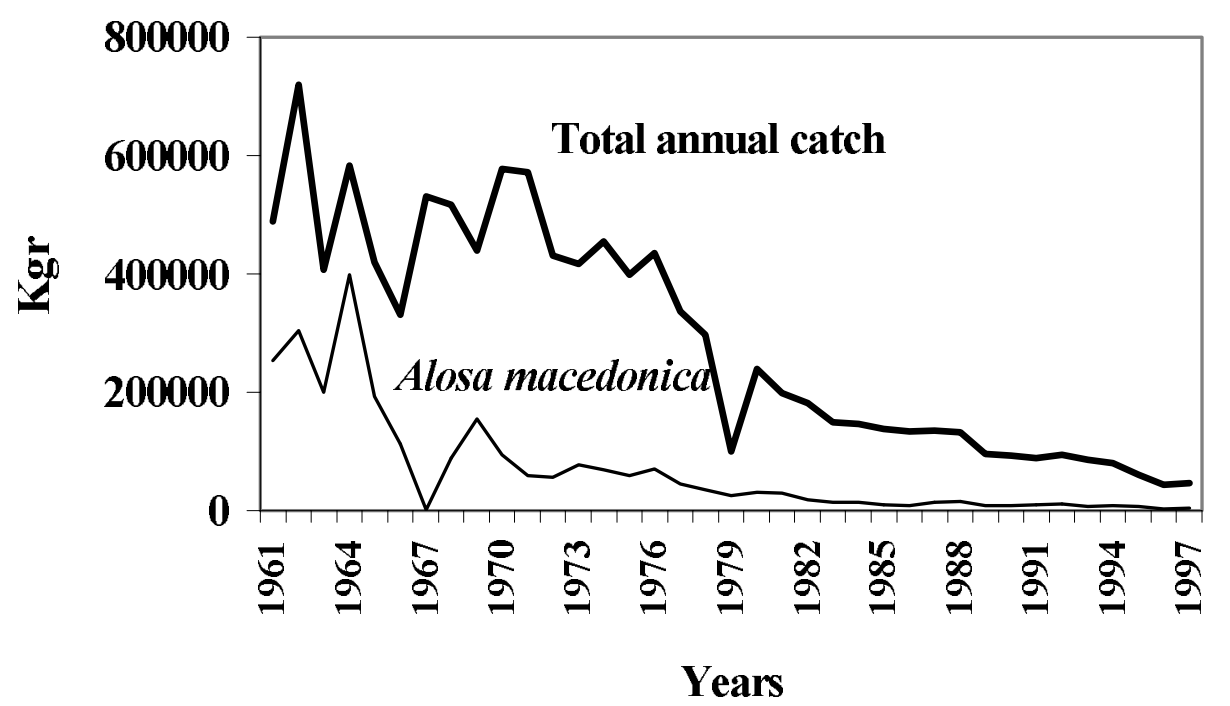

Figure 3

Annual production of $A$. macedonica and total fish catch in Lake Volvi, during the period 1961-1997.

\section{Figure 3}

Production annuelle d'Alosa macedonica et captures totales dans le lac Volvi, durant la période 1961-1997. 
In spite of its very narrow distribution restricted to lake Volvi, Macedonian shad obviously is not a threatened species because Volvi is quite controlled with only some light disturbances. Thus, the life history of this species is rather equilibrate and there is apparently no danger for it in the near future. However, the recent fishing management because of the unbalanced harvest, leads to an almost low and irregular exploitation of the population. Consequently, given that Volvi consists a small closed system, when overpopulation of the species appeared, poorly nourished, even starved, specimens are more frequent. To keep the population in balance, it is proposed to use as a management tool, a TAC (Total Available Catch) method. This management is also expected to reduce predation upon the zooplankton community of the lake and the feeding competition with several other fish species.

Alosa vistonica (Economidis and Sinis, 1986) (Thracian shad or Thritsa) (Figure 4) is endemic to lake Vistonis, which is connected with a channel with the Thracian Sea in the North Aegean, and hence has conditions similar to a lagoon. The species has been described as a sub-species, under the name Alosa caspia vistonica, by ECONOMIDIS and SINIS (1986) which was kept in several later publications (ECONOMIDIS 1991, ECONOMIDIS and SINIS, 1991b). However, KOTTELAT (1997), revising the systematic situation of Alosa caspia ranked vistonica to a valid species level. Morphologically the Thracian shad resembles the Macedonian shad by having teeth on the palatines and vomer, but clearly a lower number of gillrakers (78-97).

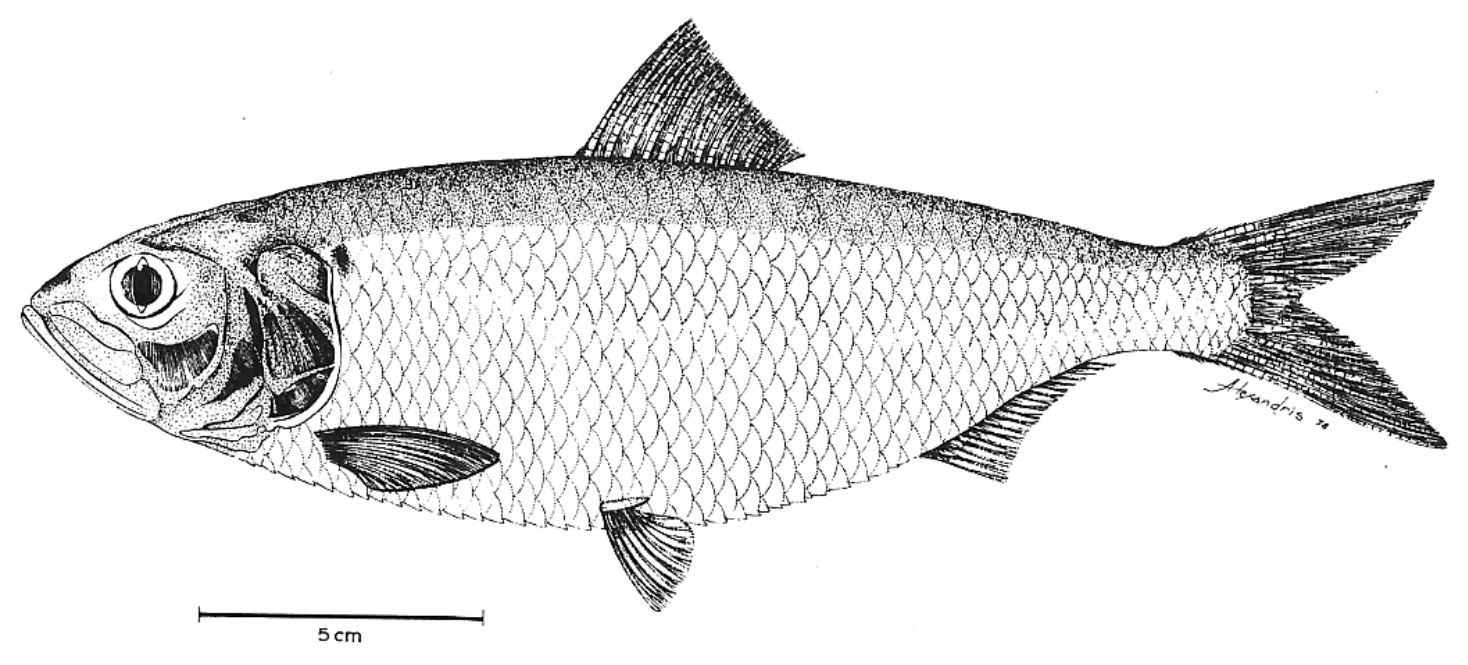

Figure 4

Alosa vistonica (Economidis and Sinis, 1986) (from ECONOMIDIS and SINIS, 1986).

\section{Figure 4}

Alosa vistonica (Economidis et Sinis, 1986) (d'après ECONOMIDIS et SINIS, 1986).

According to ECONOMIDIS and SINIS (1986) Thracian shad, as Macedonian shad, apparently originates from ancestors that came from the Pontocaspian basin and adapted in the lake Vistonis catchment. During an interglacial period of the Quaternary, characterized by low salinity, the species became isolated in the lacustrine part of Vistonis, not being able to pass through the barrier of high salinity of the North Aegean Sea (Thracian Sea). In the lower part of Vistonis, where brackish water dominates, Alosa fallax is also present as it enters easily from the open sea. However, no common schools of 
these two species have been observed (ECONOMIDIS and SINIS, 1991b). The fact that the Thracian shad has not been reported in the nearby rivers (Nestos and Evros) confirms the hypothesis that the species has no migratory habits.

The population of the species in the lake Vistonis has become very rare and thus no longer has commercial importance. This could be ascribed to the propagation of saline waters up to the lacustrine part of the system frequented before by this species, to the pollution by urban and agricultural sewage and to the changes in its habitat. So, it should be characterized as a highly endangered or extinct species, which is already included in the List of the Threatened Fishes of Europe.

Alosa fallax (Lacépède, 1803) (Twaite shad or Sardelomana) occurs across coastal zones of Greece, mainly near estuaries, because of its anadromous habit undertaking breeding migrations in rivers for spawning. Its presence was certified also in places far from the river mouth, like a specimen stored in the fish collection of the School of Biology of the Aristotle University, which was caught in the stream Ardas tributary of river Evros, more than $120 \mathrm{~km}$ away from the sea. Other specimens are also caught by trawler in the sea (Thermaikos gulf), but not so far from the estuaries of the rivers Aliakmon, Loudias and Axios. Actually, the presence of the species has been confirmed in the rivers Evros, Nestos, Strymon (Thrace and Macedonia), Pinios (Thessaly), Acheloos and Thyamis (western Greece), where it is occasionally fished mainly near their estuaries (Figure 1). As it has mentioned above, the species also occurred in lake Vistonis, which is connected with the Thracian Sea through a channel $500 \mathrm{~m}$ long ( $60 \mathrm{~m}$ width and $2 \mathrm{~m}$ depth). There is also strong evidence that it enters some other rivers such as Loudias (Macedonia), Louros and Arachthos (western Greece).

In the river Evros the species migrates from the end of March till the end of May each year. Specimens are mature and spawn in the north part of the river delta, about or more than $20 \mathrm{~km}$ from the sea. For fishing it, local fishermen close parts of the river with net and trap the fish during upstream migration. Such fish can reach 2-3 kg. In lake Vistonis mature specimens are captured from April to June, when they migrate towards the north part of the system where the lacustrine environment dominates. Several specimens from the lake are stored in the fish collection of the School of Biology of the Aristotle University. In river Nestos the species no longer migrates because of the low flow due to the construction of a dam near the Bulgarian borders. There is no recent information on the species migration and capture in the river Strymon, which is embanked and dammed, since local fishermen no longer show interest in them. However, a young individual was caught in the river delta in December 1997 (99 mm TL). So, it can be assumed that Twaite shad's reproduction is still possible in some parts of this river and probably occurs in the same season as in the other parts of northern Greece (April-June).

\section{DISCUSSION}

It is supposed that many, diadromous or brackish water living, Pontocaspian fish species, are adapted to live and/or to move through water of low salinity (less than $19 \%$ ). Otherwise it cannot be explained why only very few of them were able to adapt and to establish permanent populations in the Mediterranean. The isolation of $A$. macedonica and A. vistonica in lakes Volvi and Vistonis respectively is probably dated back to the fresh or brackish water phase of the North Aegean Sea, i.e. before the last transgression of the Mediterranean and the rise of its salinity almost up to the present levels. Consequently, the higher salinity prevailing in the North Aegean Sea when compared to the Black Sea played the role of a barrier that prevented the spreading of the two species throughout the Aegean Sea. The phylogenetic relationship of these two shad species with the subgenus Caspialosa of the Pontocaspian basin, mainly because of the existence of weak teeth on 
the palatines and the vomer, confirms the close relationship of the ichthyofauna of the fresh and brackish water in the North Aegean Sea and that of the Pontocaspian basin.

Regarding the present situation of no seriously threatened shad species in Greece (Macedonian and Twaite shad), it is obvious that a conservation status should be established soon for them, just to face the increasing anthropogenic impact, mainly dam construction and discharge of pollutants. As it is well know dams modify the seasonal patterns of river run off to which the organisms have become adapted over long periods of time, often leading to major disruption of biological events in coastal waters. Moreover, in warm, dry climates storage of water in reservoirs is associated with a great loss by evaporation, so that the total loss is considerably diminished (MANN and LAZIER, 1996). Especially, dam construction appears to have had a greater impact upon riverine fishes than any other human activity (PETTS, 1984). In Spain, for instant, all anadromous and catadromous species, especially lamprey, sturgeon, shads and eel, are threatened and included in the Spanish Red Data Book, due to the blockage of fish movements caused by dam construction (NICOLA et al., 1996). Similar phenomena now appear in several Greek rivers, where dams are constructed (Nestos and Strymon), so Twaite shad is mainly prohibited from moving upstream for spawning, because of the very low water depth during spring time.

However, pollution influences Twaite shad movements in rivers. The most important case concerns the upstream migration of the species in river Pinios (Thessaly). This river drains a lowland plain with intense agricultural activities and receives, irregularly, quantities of pesticides and sewage effluents of several cities, etc (about 250000 inhabitants). Several times, during the acute increase of the pollutants in the river, mass mortality phenomena have been observed.

Regarding the conservation status of the Thracian shad in lake Vistonis, it can be noted that according to all available information and estimation (see above) it is perhaps extinct. However there is a possibility that a very small population survives in several channels or streams outflow into the lake (mainly Kompsatos). This is why it is extremely difficult to be detected and so to confirm its presence in the system.

\section{REFERENCES}

BERG L.S., 1933. Ubersicht der Verbreitung des Süsswasserfische Europas. Zoogeographica, 1, 107-208.

BERG L.S., 1948. Freshwater Fishes of USSR and Adjacent Countries. Vol. 1, English translation, IPST, Jerusalem 1962, 504 p.

ECONOMIDIS P.S., SINIS A.I., 1986. Situation taxonomique et comparaisons des Aloses (Pisces, Clupeidae) provenant des lacs Volvi et Vistonis (Grèce). Description d'une nouvelle sous-espèce : Alosa caspia vistonica. J. Nat. Hist., 20, 723-734.

ECONOMIDIS P.S., 1991.Check list of freshwater fishes of Greece (recent status of threats and protection). Hellenic Society for the Protection of Nature. (special publication) $48 \mathrm{p}$.

ECONOMIDIS P.S., SINIS A.I., 1991a. Alosa macedonica (Vinciguerra, 1921). In: Handbook of Freshwater Fishes of Europe, Clupeidae, Anguillidae (HOESTLANDT H., ed.) 3, 297-308, Aula Verlag, 448 p.

ECONOMIDIS P.S., SINIS A.I., 1991b. Alosa caspia vistonica Economidis and Sinis, 1986. In: Handbook of Freshwater Fishes of Europe, Clupeidae, Anguillidae (HOESTLANDT H., ed.) 3, 199-209, Aula Verlag, 448 p.

KOTTELAT M., 1997. European freshwater fishes. Biologia 52/Suppl., (5), 271 p.

MANN K.H., LAZIER J.R.N., 1996. Dynamics of marine ecosystems : biological - physical interactions in the oceans. Blackwell Science Inc., $2^{\text {nd }}$ ed., $394 \mathrm{p.}$ 
NICOLA G.G., ELVIRA B., ALMODOVAR A., 1996. Dams and fish passage facilities in the large rivers of Spain : effects on migratory species. Arch. Hydrobiol. Suppl., 113 (1-4), 375-379.

PETTS G.E., 1984. Impounded rivers : perspectives for ecological management. John Wiley and Sons, Chichester, $326 \mathrm{p}$.

PSILOVIKOS A.A., 1977. Paleogeographic development of the Basin and the Lake of Migdonia (Langada and Volvi area Greece). Doctorate dissertation, Aristotle University, School of Geology, 156 p. (in Greek with English summary).

SINIS A.I., 1981. Autoecology of the endemic species Alosa (Caspialosa) macedonica (Vinciguerra) (Pisces : Clupeidae) of the Lake Volvi. Doctorate Dissertation, University of Thessaloniki, 198 p. (in Greek).

SINIS A.I., KATTOULAS M.E., 1986. Population structure of Alosa macedonica (Vinc., 1921) (Pisces : Clupeidae) in Lake Volvi (Macedonia, Greece). Cybium, 10 (1), 91101.

SINIS A.I., KALFA-PAPAIOANNOU A.M., 1988. Ergasilosis of the Alosa macedonica (Vinc., 1921) in the Lake Volvi (Macedonia, Greece). Biologia Gallo-hellenica, 14 (1), 27-31.

SVETOVIDOV A.N., 1952. Clupeidae. Fauna of the USSR. Vol. II, No 1. English translation, Jerusalem 1963. 428 p.

WHITEHEAD P.J.P., 1985. FAO Species Catalogue Vol. 7. Clupeoid fishes of the world. An annotated and illustrated catalogue of the herrings, sardines, pilchards, sprats, shads, anchovies and wolf-herrings. Part 1. Chirocentridae, Clupeidae and Pristigastridae. FAO Fish. Synop., (125), Vol. 7, Pt. 1, 303 p.

ZARFDJIAN M.E., ECONOMIDIS P.S., SINIS A.I., 1995. Large zooplankton predation by fish in lake Volvi (Macedonia, Greece). Proceedings of the 1rst World Fisheries Congress. Theme 1 : Condition of the World's Aquatic Habitats, 267-278. 